tion in favour of the amalgamation of the agricultural department of the society and the Royal Agricultural Society, under the title of the Royal Irish Agricultural Society; after some discussion the report was carried. The following are the principal points involved in the reorganisation :-

In accordance with the agreement entered into with the Government, the principal conditions of which are embodied in the "Act for the Establishment in Dublin of a Science and Art Museum and the Development of the Library of the Royal Dublin Society.into a National Library," the property of the society in land, buildings, and collections has passed into the possession of the Government. The society will, in accordance with such agreement, receive the sum of $10,000 \%$, which will be ininvested in such security as, subject to the approval of the Treasury, may be selected; it will continue to be provided with the requisite accommodation in Leinster House ; the members will have free access to the several departments as heretofore, whilst the existing members, as well as all those who shall be admitted before January I next, will have the right to borrow books from the National Library. In order to assist in the more complete development of that part of the society's work which is devoted to the promotion of science and the useful arts, it has been arranged that all the scientific serials and transactions of learned societies, as well as all duplicates in the library, shall remain the property of the society; the Lecture Hall and Laboratory will be reserved for its use; and the collections in the Botanic Garden and Museum of Natural History will be available as formerly for the illustration of papers read before the society. The most important condition, however, for the successful prosecution of the society's scientific work, pure as well as applied, is that for five years the cost of printing the scientific papers read before the society will be defrayed by the Government. Concessions equally favourable have been obtained for the agricultural department: Thus in lieu of the premises around Leinster House, which will be required for museum buildings, \&c., the Government has undertaken to provide accommodation for agricultural shows elsewhere, and to reimburse the society for any pecuniary loss it may sustain in consequence of the change of site from the city to the suburbs. In order to develop the scientific work of the society, and thus secure to the fullest extent the great advantage of having the scientific papers read before it, printed, the Committee of Science have submitted a scheme for the complete reorganisation of the department under their superintendence. Thus, the meetings for the discussion of subjects connected with science pure and applied will be held in these sections :- - I. For the physical and experimental sciences. 2. For the natural science, including geology and physical geography. 3. Science applied to the useful arts and industries. The papers to be read at these sectional meetings will be published in $8 \mathrm{vo}$, as the Scientific Proceedings, the more important to be published in 4to, under the title of "Transactions." In order to consolidate and economise both work and time other scientific bodies have been invited to associate themselves with the work of the sections, the meetings of which will be held simultaneously on the third Monday of each month, an invitation to which the Royal Geological Society and the Scientific Club have responded. A special committee is now engaged in considering the measures most advisable to adopt with regard to the future of the society, so as to maintain it as an object of attraction to the educated classes, and a preliminary report has been presented to the council, in which it is advised that in addition to the more complete organisation of the scientific department steps should be taken to render the reading-rooms more efficient, to establish a lending library for the use of future as well as present members, to arrange for the delivery of lectures for the elucidation of the latest discoveries in science, and to hold occasional conversaziones. According to one of the conditions contained in Lord Sandon's letter of February $9, \pm 876$, the National Library will be placed under the superintendence of a council of twelve trustees, eight of whom are to be nominated by the Royal Dublin Society and four by the Government.

Then followed the Report of the Committees of the Royal Dublin Society and of the Royal Agricultural Society on the subject of amalgamation, which, as we have said, was adopted. The two societies will to some extent remain connected; the Agricultural Society, Lord Powerscourt stated, would be a branch of the Royal Society, though under differer.t management.

\section{O.V THE EOCENE FLORA OF BOURNEMOUTH}

$D^{U}$

URING this last summer and autumn I have seized several opportunities of continuing my examination of the Bagshot Beds of Hampshire and the Isle of Wight, some of the results of which I think may interest your readers. This series is, as is now well known, of great importance from the fact of its being almost the only series from the tertiaries whose absolute relative geological age is positively known, it being under and overlapped on the mainland by the London clay and Bracklesham beds respectively, whilst in the Isle of Wight, occurring in a complete series of eocene strata, upheaved vertically, its true position is even still more plainly seen. It is further important as exhibiting in gradual sequence the change from an upland to a swamp flora, and represents very fairly the local flora of a long period and of an entire continent that has passed away. Of the richness and completeness of the flora an idea may be formed from the fact that I can reckon in my own collection not less than 10,000 selected specimens, many of large size, exclusive of twice that number which I have discarded, whilst there are also local collections at Bournemouth, a splendid series in the Cambridge Museum, and a scarcely less important one from Alum Bay, at the British Museum. But perhaps the most valuable discovery-to the botanist, at all events-is that of various beds containing well-preserved fruits above the horizon of the leaf-patches, identifiable with fruits from Sheppey which are found in the London clay, and therefore below the leaves. We thus appear to have at Bournemouth the leaves of trees which may be descended from those whose fruits are imbedded at Sheppey. The assistance, it will be readily seen, of the Sheppey fruits will be of the greatest value in determining the genera of the Bournemouth leaves and flowers. At Bournemouth about sixteen kinds of fruit may be collected in the seed-beds just mentioned, including Nipadites, Hightea, Cucumites, and Petrophiloides, quite sufficient to establish the fact that no break took place in the succession of the London clay flora.

The number of forms also common to Bovey Tracey is worthy of note. The most abundant fern at either locality is Pecopteris lignitum (now believed to be an Osmunda). Palmacites domonorops of Heer, from Bovey, is no other than the Cactus of which I have frequently made mention. The dicotyledons of Bovey ascribed to Laurus, Ficus, Daphnogene, Dryandroides, \&c., appear also to be identical with those of the Bagshots, and it is therefore not at all improbable that the miocene age of the Bovey Tracey beds, determined, as it seems to me, on most slender grounds, will have to be reconsidered.

The extremely local distribution of the leaves in patches, each with its distinguishing group of plants, has again in fresh instances come prominently under my notice. At Studland, in one bed, fan palms with a three-foot radius lie massed together, but in a decomposed state; and I only succeeded by using the utmost care in extracting one specimen showing the full length of the leaf, At 
Bournemouth a small bed of dark clay was found full of leaves of feather palm, crossing each other in every direction; the tip of a frond in my collection measures four feet in length, by three feet broad. Amongst other interesting specimens is a Smilax leaf of larger dimensions than any now living, and a twig of Dryandra, with many leaves attached, from Alum Bay, which unites in itself several of $M$. Watelet's species from the Grès du Soi isonnais. The discovery of a finely preserved neuropterous wing, and of two apparently hemipterous abdomens, are of interest in connection with the large series of insect remains from Gurnet Bay, Isle of Wight, lately deposited in the British Museum.

The history remains to be written of the subsidence of the great continent, whose further limits Edward Forbes surmised are yet traceable in the banks of Gulf Weed, ranging between the $15^{\text {th }}$ and $45^{\text {th }}$ parallels. Many, however, have written on Atlantis, but lacking the direct proof of its former existence in comparatively recent times, which has since come to light. The disappearance of almost an entire continent, is not a more startling proposition than the elevation of the Alps, Pyrenees, Apennines, and Carpathians, over whose highest summits the sea rolled at this period. Of the history of this disappearance Bournemouth presents us with but a page, still a page full of meaning. The incoming and disappearance in succession of oaks and beeches, figs and laurels, palms and delicate ferns, the swamp-loving aroids and Eucalyptus, Chrysodeum and Osmunda, on the same spot; the appearance in masses of the fruit of Nipa, which is stated by travellers to be found in brackish estuaries; the incoming of shore crabs and mud-boring crustacea, sea-shells and Flustra, shingle beeches and deeper sea deposits, are each well-marked stages in the history of the disappearance of this continent, whose existence at this and a later period may be gathered from the writings, made from different standpoints, of Prestwich, Godwin-Austen, Sorby, and many others. The Bournemouth and Sheppey vegetable [remains were brought down by one of the rivers draining this continent, which at a later period silted over the reptiles of Hordwell and the estuarine shells of the fluvio-marine series. That the oscillations which gradually led to the disappearance of the land, vestiges of which remain in Cornwall, the Channel Isles, Brittany, Madeira, \&c., have not ceased, even in historic times, there is ample local evidence to show. This branch of the subject, however, is scarcely yet ripe for discussion, nor would space here allow it to be fully entered into.

Baron Ettingshausen and myself are preparing a monograph upon the ferns of this flora which I hope very shortly to place in the hands of the Palæontographical Society.

J. S. GARDNER

\section{THE TELEPHONE}

$\mathrm{A}^{\mathrm{T}}$ $T$ the Society of Telegraph Engineers on the evening of October $3 \mathrm{I}$ a lecture of great interest was given by Prof. Graham Bell on the Telephone, with the invention and improvement of which his name is so intimately connected. The lecture was largely illustrated by diagrams, to which Prof. Bell made constant reference, and with these illustrations will be published at length in the forthcoming part of the Fournal of the Society. We have already given a full account of the telephone and its principles, and will only now refer to some of the interesting episodes which occurred in the course of Prof. Bell's experiments.

Prof. Bell's account of his experiments for devising methods of exhibiting the vibrations of sound, specially for use in teaching the deaf and dumb, is very interesting. For some time he carried on experiments with the manometric capsule of Koenig, and with the phonautograph of Léon Scott, He was led to the idea of constructing a phonautograph modelled closely on the mechanism of the human ear, and at the suggestion of Dr. C. J. Blake, he made use of the human ear itself, a specimen of which was prepared by Dr. Blake, for conducting these experiments.

It occurred to him that if a membrane as thin as tissue paper could control the vibration of bones that were, compared to it, of immense size and weight, why should not a larger and thicker membrane be able to vibrate a piece of iron in front of an electro-magnet, in which case the complication of steel rods in his first form of telephone could be done away with, and a simple piece of iron attached to a membrane be placed at either end of the telegraphic circuit.

The form of apparatus he was then employing for producing undulatory currents of electricity for the purposes of multiple telegraphy he describes thus : a steel reed was clamped firmly by one extremity to the uncovered leg of an electro-magnet, and the free end of the reed projected above the covered leg. When the reed was vibrated in any mechanical way, the battery current was thrown into waves, and electrical undulations traversed the circuit, throwing into vibration the corresponding reed at the other end of circuit. He immediately proceeded to put his new idea to the test of practical experiment, and for this purpose he attached the reed loosely by one extremity to the uncovered pole of the magnet, and fastened the other extremity to the centre of a stretched membrane of goldbeater's skin. He presumed that upon speaking in the neighbourhood of the membrane it would be thrown into vibration and cause the steel reed to move in a similar manner, occasioning undulations in the electrical current that would correspond to the changes in the density of the air during production of the sound; and he further thought that the change of the intensity of the current at the receiving end would cause the magnet there to attract the reed at that end in such a manner that it should copy the motion of the reed at the transmitting end, in which case its movements would occasion a sound from the membrane there similar in timbre to that which had occasioned the original vibration.

The results, however, were unsatisfactory and discouraging. With a reduction, however, in the size and weight of the spring employed, distinctly audible effects were obtained. "I remember," Prof. Bell said, "an experiment made with this telephone, which at the time gave me great satisfaction and delight. One of the telephones was placed in my lecture-room in the Boston University, and the other in the basement of the adjoining building. One of my students repaired to the distant telephone to observe the effects of articulate speech, while I uttered the sentence, 'Do you understand what I say?' into the telephone placed in the lecture-hall. To my delight an answer was retumed through the instrument itself, articulate sounds proceeded from the steel spring attached to the steel membrane, and I heard the sentence, 'Yes, I understand you perfectly.' It is a mistake, however, to suppose that the articulation was by any means perfect, and expectancy no doubt had a great deal to do with my recognition of the sentence; still, the articulation was there, and I recognised the fact that the indistinctness was entirely due to the imperfection of the instrument." After a time he produced a form of instrument which served very well as a receiving telephone; and it was in this condition his invention was exhibited at the Centennial Exhibition in Philadelphia. It was in this condition also that Sir William Thomson exhibited the instrument to the British Association in Glasgow.

In pursuing his investigations Prof. Bell has come across many interesting facts which we regret we cannot refer to in detail. It has long been known that when an intermittent current of electricity is passed through the coils of an electro-magnet a musical tone proceeds from the magnet. "I have discovered," he said, "that these sounds 